\title{
'n Prakties-teologiese perspektief op die handeling van kerklike besluitneming - verkenning en normatiewe gesigspunte
}

\author{
F.W. de Wet \& F.P. Kruger \\ Skool vir Kerkwetenskappe \\ Potchefstroomkampus \\ Noordwes-Universiteit \\ POTCHEFSTROOM \\ E-pos: fritz.dewet@nwu.ac.za \\ ferdikruger@mweb.co.za
}

\begin{abstract}
A practical-theological perspective on the act of making ecclesiastical resolutions - exploration and normative points or view
\end{abstract}

From the ecclesiastical praxis it seems that in certain cases even resolutions that were considered to be handled prayerfully under guidance of the Spirit are met with resistance. In the light of this problematic praxis, the following research question has been formulated for this research project: Up to what extent does the problematic praxis with respect to ecclesiastical resolutions flow from an oversimplified perception concerning the pneumatological dynamics involved in resolutions of which it is said: "The Holy Spirit and we resolved"? In order to address this research question, the problem field is investigated with the present theological vantage points concerning the explanation of the resolution process as departure point. The research field is further explored by trying to come to grips with the sociological and psychological factors that influence human behaviour during the resolution-making process. In an investigation into normative vantage points, the pneumatological field that unfolds when a resolution of "The Holy Spirit and us" materialises, is explored from Acts 15 . The researchers reach the conclusion that the process of making ecclesiastical resolutions is indeed a complex process. This process can degenerate into polarisation when a sound balance between anthroponomic and teonomic factors is not maintained. 


\section{Opsomming}

\section{'n Prakties-teologiese perspektief op die handeling van kerklike besluitneming - verkenning en normatiewe gesigspunte}

Uit die kerklike praksis blyk dat selfs besluite waarvan daar gesê word dat die besluitnemingsproses biddend hanteer is en dat daar aanvaar moet word dat die uitslag 'n aanduiding is van hoe die Gees die vergadering gelei het, met weerstand begroet word. In die lig van hierdie problematiek is die volgende navorsingvraag vir hierdie navorsingsprojek geformuleer: In hoe 'n mate het die problematiese praksis rondom kerklike besluitneming te make met 'n oorvereenvoudigde persepsie rakende die pneumatologiese dinamika wat ter sprake kom in besluite waarvan gesê word: "die Heilige Gees en ons het besluit"? Ten einde hierdie navorsingsvraag te antwoord, word die probleemveld uit bestaande teologiese invalshoeke verken vir die inrigting van bes/uitnemingsprosesse asook uit metateoretiese waarnemings oor menslike gedrag in die spanningsveld wat in besuitneming ter sprake kom. In 'n ondersoek na normatiewe gesigspunte word die pneumatologiese veld wat ontplooi wanneer 'n besluit van "ons en die Heilige Gees" geneem word, vanuit Handelinge 15 verken. Die navorsers kom tot die konklusie dat kerklike besluitneming 'n komplekse proses is wat in polarisasie kan ontaard weens 'n versteuring van die gesonde balans tussen antroponome en teonome faktore.

\section{Inleiding}

Kerke probeer gewoonlik in hulle besluitneming die Skrif naspreek en beroep hulle op die leiding van die Heilige Gees (vgl. Van Wyk, 2009:7). Daarom is besluitneming by kerklike vergaderings ' $n$ gewigtige saak wat nie op 'n eiewillige manier hanteer kan word nie. Vorster (2008:8) stel die implikasies van 'n besluit waarvan daar gesê word dat dit onder leiding van die Heilige Gees geneem word dat afgevaardigdes die belangrike taak het om na die Skrif te luister, maar ook om na mekaar te luister en om gehoorsaam te wees aan die leiding van die Heilige Gees. De Klerk (2000:335) beklemtoon dat 'n goeie gewete in die proses van besluitneming alleen deur die Woord van God gebind kan word. Die outeurs wil graag hierdie artikel opdra aan Ben de Klerk. Op wetenskaplike vlak en in advies aan kerke is hy vir sy medegelowiges die toonbeeld van iemand wat in nederige gehoorsaamheid altyd die wil van God in sy Woord soek. 
Waar daar sprake is van ' $n$ vergadering van mense wat veronderstel is om hulle deur één Woord en één Gees te laat lei, sou daar verwag kon word dat besluitneming tot 'n groot mate 'n karakter van kohesie en eenstemmigheid sou openbaar. Die praksis van kerklike besluitneming toon egter dat daar dikwels lewendige debatte gevoer word, wat gekenmerk word deur ernstige meningsverskille. Van Wyk (2009:7) onderskei byvoorbeeld drie teologiese debatte wat tans in Suid-Afrika gevoer word.

- Die interne debatte in elk van die drie tradisionele Afrikaanse kerke, die Nederduitse Gereformeerde Kerk (NGK), die Nederduitsch Hervormde Kerk van Afrika (NHKA) asook die Gereformeerde Kerke in Suid-Afrika (GKSA). Veral drie sake oorheers in hierdie debatte, naamlik die eenheid van die kerk, die kerklied en die vrou in die amp.

- Die debat tussen die "ortodokse" en "modernistiese teoloë" wat handel oor die noodsaaklikheid al dan nie van 'n herinterpretasie van die evangelie.

- Die derde debat tussen die ateïsme en die Christelike geloof.

By die debatte hierbo genoem, sou sekerlik ook die uiteenlopende standpunte gevoeg kon word rakende saamwoon en seksualiteit. Besluite wat voortvloeiend uit sodanige debatte in kerklike vergaderings geneem word, word oënskynlik dikwels in 'n besluitnemingsomgewing geneem wat deur die spanningsveld van polarisasie gekenmerk word. 'n Saak waaroor daar ernstige meningsverskille en gepolariseerde standpunte bestaan, word tot stemming gebring (daar moet tussen óf die een standpunt, óf die ander gekies word) en die meerderheidstem gee die deurslag aan die besluit wat uiteindelik geneem word. Uit die manier waarop daar op sodanige besluite in die kerklike praksis gereageer word, blyk dat die meningsverskille wat die besluit voorafgegaan het, steeds ná besluitneming funksioneer en selfs tot verskeurdheid kan ontwikkel. Selfs besluite waarvan daar gesê word dat die besluitnemingsproses biddend hanteer is en dat daar aanvaar moet word dat die uitslag ' $n$ aanduiding is van hoe die Gees die vergadering gelei het, word met weerstand begroet.

In hierdie navorsingsprojek wil die navorsers die probleemveld van kerklike besluitneming vanuit die invalshoek van prakties-teologiese besinning verken. In die Praktiese Teologie word die geloofshandelinge van mense bestudeer (Heyns \& Pieterse, 1990:7). Firet (1987: 260) het die geloofshandelinge teologies veranker in 'n bepaalde 
raamwerk, naamlik die handelinge in diens van die evangelie. Heitink (1999:193) beskryf die sentrale probleem in die Praktiese Teologie as 'n hermeneutiese vraag na die manier waarop die goddelike en menslike realiteit met mekaar op ervaringsvlak verbind kan word. Pieterse (2005:78) ontleed hierdie spanning verder en maak die afleiding dat die postmoderne Westerse geestesklimaat van 'n sterk antroposentriese gees getuig waarin die mens die sentrum van alles is. Sodoende verdwyn die goddelike werklikheid (die teonome) uit die denkwêreld van moderne mense. De Wet (2009:2) omlyn in resente navorsing die unieke invalshoek van prakties-teologiese navorsing as die manier waarop op die snyvlak tussen goddelike en menslike elemente gefokus word in die verstaan, verklaring en verandering van die praksis van die geloofslewe. In hierdie navorsingsprojek word aansluiting gevind by laasgenoemde invalshoek en word gefokus op die manier waarop die moontlikheid van oorvereenvoudigde persepsies rondom die verhouding tussen goddelike en menslike handelinge in besluitnemingsprosesse tot 'n problematiese praksis aanleiding kan gee.

Vanuit die prakties-teologiese invalshoek word in hierdie studie met die volgende navorsingsvraag gewerk: Tot watter mate het die problematiese praksis rondom kerklike besluitneming te make met 'n oorvereenvoudigde persepsie rakende die pneumatologiese dinamika wat ter sprake kom in besluite waarvan gesê word: "die Heilige Gees en ons het besluit"? Dit gaan in hierdie navorsingsvraag dus oor die rol wat oorvereenvoudiging kan speel wanneer daar nie genoegsaam rekening gehou word met die manier waarop menslike voorkeure en denkraamwerke (antroponome elemente) - dikwels onbewustelik - 'n oorheersende invloed kan hê in die manier waarop die Woord en Gees (teonome elemente) in besluitneming ter sprake gebring word nie.

Dingemans (1996:62) wys daarop dat die meeste praktiese teoloë deesdae drie dimensies in prakties-teologiese ondersoek onderskei, naamlik:

- die analiserende beskrywing van die prakties-teologies situasie;

- die ondersoek na normatiewe gesigspunte; en

- die ontwikkeling van veranderingstrategieë op grond van die beskrywing van normatiewe uitgangspunte.

In hierdie projek maak die navorsers gebruik van hierdie driedeling deur te begin met ' $n$ analise van die praksis en ' $n$ oriëntasie ten opsigte van die probleemveld. Tydens hierdie eerste fase van die 
navorsingsprojek word voorbeelde van navorsing en refleksie rondom die probleemveld in oënskou geneem, die bestaande teologiese invalshoeke en grondslae vir die inrigting van kerklike besluitnemingsprosesse word verken en metateoretiese waarnemings word oor menslike gedrag gemaak in die dinamika van besluitnemingsprosesse in die konteks van verandering.

In die tweede fase van die navorsingsprojek word 'n ondersoek gedoen na normatiewe gesigspunte. Vanuit Handelinge 15 word die pneumatologiese veld verken wat ontplooi wanneer 'n besluit van "ons en die Heilige Gees" geneem word. In hierdie verkenning word besondere aandag gegee aan die hermeneutiese elemente wat in Skrifhantering ter sprake kom met die oog op besluitneming. Basisteoretiese merkers word geïdentifiseer vir die verruimde perspektief wat nodig is om die probleem te deurbreek van 'n oorvereenvoudigde persepsie rondom die verhouding tussen teonome en antroponome. (Fase een en fase twee van die navorsingprojek word in hierdie eerste artikel in 'n reeks van twee gedokumenteer.)

In die derde fase van die navorsingsprojek word praktykteoretiese riglyne ontwerp vir die veranderingstrategieë wat nodig is om besluite te neem waarin die eer van God en die eenheid in die kerk gedien word. (Fase drie van die navorsingprojek word in 'n opvolgartikel gedokumenteer.)

\section{Verkenning van problematiek rondom kerklike besluitneming}

\subsection{Voorbeelde van navorsing en refleksie rondom die probleemveld in die gereformeerde denkwêreld}

Oor die teologiese grondslae van kerklike besluitneming en die spanningsvelde wat in die proses van hierdie besluitneming ter sprake kom, is daar die afgelope twintig jaar wyd besin en die seleksie, die aktualiteit van die onderwerp en die omvangrykheid van die probleemveld blyk uit die literatuur (Dudley \& Hilgert, 1987:104; Van Wyk, 1990:265; Snyman, 1992:351; Burger, 1995:48; Smit, 1995: 121-122; Van't Spijker, 1993:445; Jordaan, 1997:6; De Klerk, 2000: 334; Niemandt, 2007:52; Van der Watt, 2007:75; Vorster, 2008:8-9). In die ter saaklike teologiese literatuur word 'n verskeidenheid perspektiewe gebied:

- Nel (2003:116) belig die kritiek teenoor die kerk, vanweë die feit dat kerklike vergaderings die een oomblik besluit dat die Bybel 'n antwoord gee net om daarna weer van besluit te verander. Die 
kritiek wat geopper word, is dat kerklike vergaderings lidmate met besluite mislei (Nel, 2003:116).

- Snyman (1992:351-353) wys in sy navorsing op die spanning wat sedert die negentigerjare onder andere in die GKSA opgelaai het betreffende kerklike besluitneming. Hy het verder in die kerklike besluitneming sosiologiese ondertone bemerk, wat hy beskryf as 'n verskuiwing in geloofwaardigheidstrukture (Snyman, 1992: 352).

- Burger (1995:48-50) is in sy navorsing meer genuanseerd deur die aandag daarop te vestig dat formele besluitneming in oorgangstye groot eise aan kerkgemeenskappe stel. Hiermee toon Burger (1995:48) die gevaar aan dat kerklike vergaderings kan oordeel dat indien ' $n$ formele besluit geneem is, die belangrikste deel van hulle opdrag voltooi is. Hy bepleit in sy studie die noodsaaklikheid daarvan dat besluitneming ook moet fokus op die refleksie hoedanig gelowiges hierdeur opgebou kan word (Burger, 1995:49).

- Smit (1995:121) wys op sy beurt op die tendens by kerklike vergaderings dat die beslissing na afloop van vergaderings, ongeag of daar nog verskille mag bestaan, gefél word deur die blote tel van stemme. Hy bemerk in hierdie tendens 'n gebrekkige konflikhantering asook 'n gesekulariseerde benadering tot besluitneming.

- Dudley en Hilgert (1987:104) lig die uniekheid van die vroeë kerk uit wat konflik konstruktief kon aanwend om die kerk op te bou.

- Vroeër het Van Wyk (1990:265) hom ook vanuit 'n etiese hoek besig gehou met die vraag oor hoe God se wil in wisselende lewensomstandighede geken en gehoorsaam kan word. Dit bring hom (Van Wyk, 1990:266) by die vraag of daar van direktiewe of determinante in besluitneming sprake kan wees.

- De Klerk (2000:335) benadruk in sy navorsing oor besluitneming die gevaar van gewetensbinding. 'n Goeie gewete kan alleen deur die Woord van God gebind word. Daarom word 'n goeie gewete voortdurend aan die betroubare Woord getoets (vgl. Blackaby \& King, 2002:164).

- Na afloop van die algemene sinode van die GKSA in 2009 waar ' $n$ besluit oor geslagtelikheid en bevestiging in die diens van ouderling en predikant geneem is, spreek Pienaar (2009:8) in 'n redaksie-artikel in die Kerkbode sy kommer uit oor die uiteenlo- 
pende maniere waarop vergaderings die Bybel gebruik. Pienaar bestempel selfs die besluit van die GKSA oor die nie-toelating van vroue in die amp van ouderling en predikant as 'n verleentheid wat hulle so gou as moontlik sal wil regstel.

- Snyman (2009:9) spreek in dieselfde uitgawe van die Kerkbode sy kommer daaroor uit dat daar "geen blyke van die etiek van Bybellees" is nie.

Hierdie verkenning maak dit duidelik dat hierdie 'n omvangryke problematiek is. Die problematiek wissel van onkonsekwentheid in Skrifgebruik, binding aan besluite waarvan die geloofwaardigheidstrukture in twyfel getrek word en polarisering in besluitneming (óf-óf-besluite waarin daar nie ruimte vir 'n én-én-uitkristallisering van die besluitneming is nie). Die navorsers werk met die hipotese dat ' $n$ oorvereenvoudigde persepsie ten opsigte van die manier waarop (verborge) antroponome elemente die teonome elemente (bepaaldheid deur Woord en Gees) kan manipuleer, moontlik tot 'n groot mate 'n rol kan speel in die problematiese elemente wat hier aangedui is.

\subsection{Bestaande teologiese invalshoeke en grondslae vir die inrigting van kerklike besluitnemingsprosesse}

Besinning oor kerklike besluitneming kan vanuit verskeie invalshoeke geskied, vanweë die verskillende perspektiewe waarmee die onderskeie studievelde in die teologie hierdie saak en die probleemveld waarin dit plaasvind, sal benader. Daarom wil die navorsers rekening hou met die feit dat daar vanuit die studievelde van onder andere Kerkreg en Etiek asook ander dissiplines, telkens 'n eiesoortige perspektief op die problematiek wat in kerklike besluitneming ter sprake kom, verkry kan word. In aansluiting by mekaar bied hierdie perspektiewe verruiming en verdieping in die blik waarmee na die probleemveld gekyk word.

In die verkenning van die probleemveld vanuit 'n prakties-teologiese invalshoek sal daarmee rekening gehou moet word dat die aanverwante dissipline van Kerkreg nog altyd 'n belangrike rol gespeel het in gereformeerde denke rakende die manier waarop daar tot verantwoordelike besluitneming gekom word. Kerklike besluitneming is in die gereformeerde denkraamwerk eerstens - en selfs by uitstek - 'n saak vir die Kerkreg. In die gereformeerde beskouing oor kerkregering is dit ' $n$ kardinale uitgangspunt dat Jesus Christus die enigste Hoof van die kerk is. Hierdie klem vind derhalwe ook vergestalting in die gereformeerde belydenis (NGB, artikel 30). In die 
kerkregering bestaan daar daarom 'n geestelike regeringswyse (Smit, 1992:507). Kerklike vergaderings het geen eie regeringsmag nie, maar oefen die bediening van Christus se regering uit (Smit, 1992:508). Calvyn het dit eens gestel dat Christus die voorsitter van enige kerklike vergadering moet wees, en $\mathrm{Hy}$ is dit eers wanneer die vergadering in al sy besluite ooreenkomstig die Woord, deur die Gees gelei word (Calvyn, 1956; 4.9.1). Hierdie kerkregtelike grondlyne word deurgaans in die navorsingsprojek veronderstel, maar die navorsers wil bepaald 'n saak uitmaak vir die intradissiplinêre manier waarop verskillende teologiese dissiplines mekaar kan verryk. Praktiese Teologie kan, vanuit die invalshoeke en navorsingsfokus waarmee dit werk, 'n perspektiefverruimende bydrae lewer om moontlike eensydighede en skeeftrekkings aan te dui in die manier waarop die regering van Christus deur menslike handelinge bedien word. Praktiese Teologie se bydrae kan op die vlak lê om te verseker dat daar nie bloot eenogig na regstegniese aspekte van besluitneming gekyk word nie. Dit kan ook die teologiese spektrum verruim sodat daar nie met 'n oorvereenvoudigde blik na die dinamika gekyk word wat in 'n kerklike besluitnemingsproses plaasvind nie. Die besluitnemingsproses word deur die Woord en Gees gelei, maar het ook te doen met menslike handelinge. Sonder dat hulle dit bewustelik doen, kan mense dalk besig wees om hulle eie sienings in te klee as die wil van God waardeur die regering van Christus as die integrale Hoof van die kerk (as die enigste basis vir kerklike eenheid en eenheid in besluitneming) in gedrang gebring word.

Van Wyk (1990) het in sy besinning vanuit 'n etiese hoek oor morele besluitneming vanuit 'n Christelike perspektief aangetoon dat hierdie besluitneming op niks anders neerkom nie as die navraag na God se wil vir wisselende lewensomstandighede en gehoorsaamheid hieraan. Van Wyk (1990:266-280) laat die klem val op 'n aantal determinante in besluitneming, waarvan hier net enkeles genoem word.

- Vooronderstellings: Geen mens kan hom losmaak van bepaalde vooronderstellings in besluitneming nie. Gevaarlike vooronderstellings kan gevorm word deur eensydighede en radikalisering in faktore soos opvoeding, kultuur, posisie, situasie en ideologie. Vrees vir eensydighede kan egter nie die feit wegneem dat gelowiges uit geloofsoortuiging besluite neem nie.

- Selfverloëning: Die gesindheid wat daar in Christus bestaan, naamlik selfverloëning, behoort 'n belangrike vertrekpunt in morele besluitneming te wees. Dit wat nie uit liefde en selfverloëning gedoen (besluit) word nie, kan nie goed wees nie. 
- Die norm: Die bepalende vraag in besluitneming is die vraag na die wil van God. Teenoor die teonome bepaaldheid waarvan die Christelike benadering getuig, staan die heteronome norme soos ervaring, tradisie en gevoel. Die wil van God word in die Woord gevind. Tog is die saak nie so eenvoudig nie en daar kan nie op simplistiese wyse hierna gegryp word nie. Die Skrif bied nie 'n kasuïstiese register van moontlikhede van besluitneming nie. Die saak van Skrifberoep is dikwels problematies onder andere as gevolg van die gevare van kritisisme en fundamentalisme. Daarom is dit ' $n$ absolute voorvereiste dat wanneer daar 'n beroep op die Skrif gemaak word, dit op hermeneuties verantwoordbare wyse sal geskied.

- Die metode: Die metode wat gevolg word in besluitneming is van die uiterste belang, aangesien die verkeerde metode die saak waaroor dit gaan, kan bederf. Die wyse van besluitneming is van kardinale belang.

- Die saak: Die saak waaroor die keuse gaan, moet tot op die been oopgekloof word.

- Die oorweging: Nadenke oor 'n saak is dikwels 'n lang en moeisame proses. In hierdie proses word die Skrif en verstand gebruik, maar alles staan onder die vernuwende leiding van die Heilige Gees.

- Die gebed: Besluitneming is vir gelowiges altyd 'n biddende proses.

- Die keuse: In die keuse wat in besluitneming gemaak word, moet die balans tussen die belange van die individu en die gemeenskaplikheid van gelowiges (koinonia) verreken word. Indien dit nie geskied nie, laat dit kerkgemeenskappe verskeurd en verward.

Hierdie perspektiewe vanuit die Etiek bevestig dat kerklike besluitneming ' $n$ komplekse proses is waarin verskeie faktore 'n rol speel en dat die verantwoordbaarheid van die besluit wat geneem word, geen eenvoudige saak is nie. Weereens wil die navorsers beklemtoon dat hulle vanuit die prakties-teologiese invalshoek 'n bydrae wil maak om die elemente in die menslike handelingspraksis te identifiseer wat versteurend op die teonome bepaaldheid van 'n verantwoordbare besluitnemingsproses kan inwerk. 


\subsection{Metateoretiese waarnemings oor menslike gedrag in die dinamika van besluitnemingsprosesse in 'n konteks van verandering}

Omdat die Praktiese Teologie op die handelinge van mense in konkrete samelewingsverbande fokus, vind oorvleueling ook plaas met die ondersoekterrein van ander wetenskappe wat op menslike gedrag fokus. In sosiologiese navorsing is alreeds indringende navorsing gedoen oor die rol van oorreding en sosiale invloed op menslike gedrag en besluitneming (Noble, 2000:2 en Gass \& Seiter, 2003:3). Daarom wil hierdie navorsingsprojek ook erkenning gee aan die intradissiplinêre benadering ten opsigte van die aangrensende sosiale wetenskappe (Cartledge, 2003:15).

Burger (1994:84) het die rol van die kerk in 'n veranderende samelewing beskryf as 'n bewaringsrol. Die kerk beskik volgens bogenoemde skrywer oor iets wat verandering nie goedgesind is nie. Hieruit word die afleiding gemaak dat die saak van bewaring ook in kerklike debatte en besluitneming weerklank vind. Bogenoemde outeur toon verder aan dat die kerke in Suid-Afrika eintlik nie 'n goeie rekord het wanneer dit kom by die raaksien en hantering van verandering nie. In die lig hiervan, kan verwys word na Firet (1978:131) wat pleit vir die term agogie of begeleiding van lidmate te midde van verandering. Daarom is dit noodsaaklik dat daar in die kerk wel rekening gehou moet word met insigte rakende die verwerking van verandering soos dit deur dissiplines soos Sosiale Psigologie en Sosiologie gebied word. Pieterse (1981:92-94) wys op die gevaar dat die kerk weens 'n gebrek aan insig in die veranderingsproses dikwels in die geskiedenis die samelewing bloot volg en boetseer. Die gevaar hieraan verbonde is dat, indien die kerk nie in normale omstandighede kan aantoon wat die Skrif leer nie, dit in veranderingstye soveel te meer sal sukkel om dit reg te kry. Dit is daarom noodsaaklik om dit wat ander menswetenskaplike dissiplines ondersoek oor veranderings in die samelewing en insigte in die maniere waarop verandering bestuur behoort te word, in berekening te bring in prakties-teologiese navorsing.

\subsubsection{Metateoretiese perspektiewe vanuit die Sosiologie}

Volgens Noble (2000:172) is daar prosesse van integrasie sowel as disintegrasie aan die werk in die samelewing. Kragtens die sisteemteoretiese insigte waarmee in die Sosiologie gewerk word, moet die wyse waarop mense mekaar beïnvloed globaal in terme van die werking van sosiale sisteme in die samelewing beskou word. Noble (2000:184) asook Timasheff en Theodorson (1983:328- 
330) is van mening dat sosiale sisteme geïntegreer word aan die hand van 'n waardesisteem, of 'n bepaalde kultuur. Integrasie het te make met die innerlike aktiwiteit van die mens waardeur hy probeer om die ewewig te herstel wat as gevolg van versteurings (soos verandering) ontstaan het (Noble, 2000:186). In ander woorde uitgedruk, het integrasie te make met die proses waardeur individue nuwe ervarings, insigte en indrukke tot ' $n$ innerlike harmonie probeer verenig met dit wat reeds in die sisteem waarin hulle lewe vasstaan en ingebed is.

In die sosiologiese sin van die woord dui disintegrasie op die tendens waar 'n lewensterrein of 'n maatskaplike funksie die ander terreine of funksies sodanig oorheers dat een of meer van die terreine verdwyn. Faktore wat disintegrasie in 'n sosiale sisteem bevorder, is byvoorbeeld sake soos onrus, 'n krisis, die afwesigheid van 'n algemeen-aanvaarbare waardesisteem, die miskenning van die belange van ander asook die afwesigheid van veelvoudige deelname in groepe. Die bestaan van 'n gemeenskaplike strewe na 'n gemeenskaplike doelstelling kan die gevaar van disintegrasie bevorder wanneer 'n drukgroep gevorm word en minderheidsbelange van ander mense daardeur van die tafel gevee word.

Hoewel alles in die samelewing sekerlik nie tot 'n sisteem gereduseer kan word nie (vgl. Noble, 2000:200), open die sisteemteoretiese insigte waarmee in Sosiologie gewerk word 'n verruimde blik op die horison van die gevaar van disintegrasie in die kerk. Die kerk leef in 'n wêreld van verandering en kan daarom nie by die bestaan van die twee belangrike begrippe (integrasie en disintegrasie) verbybeweeg nie - veral nie in kerklike besluitneming nie. Binne 'n bepaalde samelewing kan gelowiges weens disintegrerende faktore begin ervaar dat hulle denke anders bedraad is as dié van ander gelowiges (Sweet, 2007:25). Niemandt (2007:48-50) gebruik die metafoor van die kerke wat in 'n storm verkeer om die effek van snelle veranderings tot uitdrukking te bring. Die kerk leef in 'n wegholwêreld met aanhoudende verandering wat groot eise stel. In die postmodernistiese denkklimaat gaan dit nie daaroor om alles verstandelik te wil uitredeneer nie. Gevoel en ervaring het modebegrippe geword. Kragtens hierdie denkpatroon moet alles vloeibaar en plooibaar wees - ook die waarheid. Terwyl baie lidmate dikwels nog sukkel om die denkklimaat van die Postmodernisme te begryp, praat ander geleerdes alreeds van 'n post-Christendom (Niemandt, 2007:49). Veranderings gebeur eenvoudig net te vinnig om dit op 'n integrale manier te verwerk. 
Toegepas op kerklike besluitneming, bring die insigte uit die sisteemteoretiese insigte van Sosiologie mee dat daarmee rekening gehou moet word dat gelowiges gedurig besig is om innerlik die ewewig te probeer herstel as gevolg van allerlei veranderings. Gebrekkige bestuur van verandering kan daartoe lei dat steurende invloede bloot deur besluitneming afgeweer wil word, sonder dat die kompleksiteit van die situasie en die uitdagings wat dit stel volledig verreken word.

\subsubsection{Metateoretiese perspektiewe vanuit die sosiale Psigologie}

Gass en Seiter (2003:357) ondersoek in hulle sosiaal-psigologiese navorsing die etiek van oorreding. Dit word gedoen teen die agtergrond daarvan dat oorreding dikwels beskou word as iets wat eties onaanvaarbaar is. Die misverstand verbonde aan die begrip oorreding is dat dit met manipulering verwar word (Baron \& Byrne, 1994:151). Smit en De Cronje (1999:169-170) wys op die gevaar dat oorreding maklik sinvolle kommunikasie kan versteur deurdat dit nie aanleiding gee tot onderlinge instemming nie. Hier kom die dinamika, of spanningsveld, ter sprake wat ontstaan indien persone nie met mekaar saamstem nie. Oorreding is die meganisme waarheen persone hulle wend indien hulle behoeftes nie bevredig is nie, of indien hulle verhoudings onder druk verkeer (Gass \& Seiter, 2003: 358). Die proses van oorreding wat op vertroue en onderlinge respek berus, is dus dikwels langdurig van aard, juis omdat dit die geleentheid aan gespreksgenote bied om mekaar te beïnvloed (Smit \& De Cronje, 1999:188).

Louw en Edwards (1998:709-718) asook Gass en Seiter (2003:358$360)$ vestig die aandag op twee belangrike sake ten opsigte van oorreding:

- Binne gespreksvoering speel die motief van die oorreder 'n belangrike rol. Die etiese motief van die oorreder is bepalend vir die strategie wat in die oorreding gevolg sal word.

- Kulturele en omgewingsfaktore speel in die proses van oorreding 'n vername rol. 'n Bepaalde kultuur kan byvoorbeeld 'n meer logiese beredenering volg as ' $n$ ander kultuur waar 'n emosionele aanslag meer op die voorgrond kan staan.

In die proses van oorreding onderskei Gass en Seitner (2003:363) verskeie determinante:

- Intensionaliteit: In die proses moet gespreksgenote daarmee rekening hou dat die oorreding bewustelike, maar ook onbewus- 
telike gevolge het. Soms het die oorreding, anders as wat die oorreder noodwendig bedoel het, minder goeie gevolge. In enige proses van oorreding moet met hierdie feit rekening gehou word.

- Bewustelike instemming van gespreksgenote: Gespreksgenote moet vooraf en gedurende gesprekvoering bewus wees dat die gesprek te make het met oorreding. Die bewustheid hiervan bied aan elkeen die geleentheid om sy/haar bydrae te lewer.

- Spontane en vry keuses: In spontane gesprekvoering sal gespreksgenote die geleentheid ontvang om mekaar se strategie en oorreding te bevraagteken. In die proses ontstaan die bewustheid dat die ander party niks op die ander sal forseer nie.

- Taalgebruik en simboliese optrede: In hierdie opsig is verbale of gesproke taalgebruik meer aanvaarbaar, omdat gespreksgenote van meet af aan onder die indruk van oorreding verkeer. Simboliese optrede soos betogings en stakings skep unieke probleme.

- Oorreders moet oorreding in liefde laat geskied: In hierdie opsig onderskei bogenoemde outeurs drie soorte oorreders, naamlik:

- Verleiders wat hierdie metode gebruik om ander mense mee te bedrieg.

- Verkragters wat allerlei dreigemente en waarskuwings rig om mense in 'n rigting te dwing. Gespreksgenote word deur oorreders wat in hierdie kategorie val as blote objekte beskou.

- Liefdevolle oorreders behandel ander mense as hulle gelykes. Hulle is oop vir ander se bydrae wat gelewer word en is voortdurend op die uitkyk om die aangeleentheid op te los.

Oorredingskommunikasie as die proses wat besluitneming voorafgaan, is kommunikasie wat daarop gerig is om doelbewus mense se gesindheid en gedrag te verander (Louw \& Edwards, 1998:711). Dit is egter noodsaaklik om te begryp dat gespreksgenote 'n natuurlike geneigdheid het om hulle teen oorredingskommunikasie te verset. Hierdie feit maak kerklike beraadslagings dikwels vermoeiend en uitputtend. Veral die volgende sake speel, volgens Gass en Seiter (2003:363-375), in hierdie opsig 'n rol:

- Voorafkennis dat 'n boodskap daarop gemik sal wees om verandering te bewerkstellig, gee aanleiding tot 'n psigologiese reaksie waartydens hoorders doelbewus probeer om die verandering te ignoreer. 
- Daar moet rekening gehou word daarmee dat 'n proses van verwerking nodig is. $\mathrm{Na}$ inenting ervaar 'n pasiënt 'n geringe aanval van die siekte waarteen hulle ingeënt is, maar 'n ruk daarna word die weerstand van die liggaam verhoog. Hoorders het tyd nodig om nuwe inligting van oorredingsgesprekke te verwerk.

- Die behoefte aan kognitiewe afsluiting gee aan talle gesprekvoerders 'n gevoel van sekuriteit, terwyl ander hulle opsies wil oophou. Laasgenoemde behou hulself die reg voor om hulle gesindhede te verander na gelang van nuwe inligting.

- Indien hoorders met oorredingskommunikasie gekonfronteer word, reageer hulle op verskillende wyses. Dit kan teruggevoer word na verskillende verdedigingstrategieë waarmee hulle hulleself beskerm.

\subsubsection{Samevattende metateoretiese afleidings op besluitneming}

Vanuit bogenoemde metateoretiese perspektiewe kan die volgende waarnemings ten opsigte van sosiale en psigologiese faktore gemaak word wat menslike gedrag tydens kerklike besluitnemingsprosesse kan beïnvloed:

- Kerklike besluitneming geskied nie in 'n vakuum nie. Afgevaardigdes word noodwendig deur allerlei gebeure in die samelewing beïnvloed.

- Die uitdaging word vanuit die menslike samelewing aan kerklike besluitneming gerig om met die besluit wat geneem word te integreer in plaas daarvan om te disintegreer.

- Kerkgemeenskappe disintegreer wanneer hulle in 'n besluitneming nie 'n duidelike inkorporerende besluit volgens die norme van die Skrif kan neem nie.

- Wanneer oorredingsgesprekke met die oog op besluitneming gebruik word, moet daarmee rekening gehou word dat oorreding ' $n$ fyn kuns is. Die proses van oorreding kan maklik in misleiding en manipulasie ontaard en nie rekening hou met die natuurlike geneigdheid van mense om hulle teen oorreding te verset nie. 


\section{Basisteoretiese perspektiewe op die verhouding tussen Goddelike en menslike handelinge in kerklike besluitneming (Hand. 15)}

\subsection{Inleidende opmerkings oor die verhouding tussen Goddelike en menslike elemente in die handelingspraksis van die kerk}

Louw (1993:196) pleit vir 'n gebalanseerde siening van die Godmensverhouding. Die antwoord lê vir hom opgesluit in die pneumatologie. Daarom verwys hy na die navorsing van Rebel (1982:157) wat tot die gevolgtrekking gekom het dat 'n pneumatologiese antropologie as korrektief vir 'n humanistiese mensvisie moet dien. Die verhouding tussen God en mens word in die Praktiese Teologie dikwels met die term teonome resiprositeit omskryf - 'n begrip wat oorspronklik deur Van Ruler (1969:181) gebruik is. Met die term resiprositeit bedoel Van Ruler die erkenning dat God alles op 'n teonome manier gee op sodanige manier dat Hy die mens aan die werk sit. Van Pelt (1999:260) beklemtoon dat die mens wel kragtens die werking van die Gees oor 'n outonomiteit beskik, maar 'n outonomiteit wat nie die outoriteit van die Heilige Gees aantas nie. De Wet (2005:512) verbind die werking van die Heilige Gees wat mense vry maak om kreatief en innoverend op te tree, konsekwent aan God se genade waardeur mense in Christus nuutgemaak word en in Hom leef en handel. Daarom sluit De Wet (2005:514) by die denklyn van Van Pelt (1999:272) aan wat die pneumatologie en Christologie met mekaar in verband bring. Hiervolgens staan God en mens parallel teenoor mekaar, maar is by wyse van die verbond, foederatief (blywend) op mekaar betrokke (Van Pelt, 1999:514). Met die liefde waarmee God ons eerste liefgehad het in Christus, word ons in staat gestel om God selfverloënend bo alles lief te hê en ons naaste soos onsself. Omdat Christus (wat sy lewe afgelê het) pneumatologies ín die gelowige leef, word die gelowige in staat gestel om sy/haar lewe selfverloënend en vry van eiebelang tot eer van God en die opbou van die naaste uit te giet.

In die veld van ondersoek wat handel oor besluitneming, hou bogenoemde prakties-teologiese insigte in dat kerklike besluitneming rekening moet hou met volgehoue gebed om die verligting van die Heilige Gees (Vorster, 2008:8). Die belangrike verhouding tussen die menslike verantwoordelikheid en die leiding van die Heilige Gees kom op 'n besondere wyse na vore in die kerklike vergadering in Handelinge 15. De Villiers (1987:43-44) maak die opmerking dat daar in Handelinge 'n noue verbintenis is tussen die Gees en die 
verhoogde Christus. De Villiers beskryf dit as die bemiddelende werking van die Gees waardeur die verdienste van Jesus Christus na die kerk gebring word. "Om deur die Heilige Gees vervul te wees" ('n frase wat slegs in Lukas tot Handelinge voorkom) blyk dieselfde betekenis te hê as die Pauliniese formule, "in Christus", aangesien die Gees gelowiges lei om hulle lewe in Christus te vind wat nou, deur sy Gees, by sy mense is (vgl. Suggit, 1992:41).

\subsection{Basisteoretiese perspektiewe op die verhouding tussen die teonome en antroponome aspekte in die besluitnemingsproses wat in Handelinge 15 opgeteken is}

In die gemeente van Antiochië het daar aanvanklik 'n hartlike eenheid geheers (Groenewald, 1986:464). Verdeeldheid onder die gelowiges het later ingetree as gevolg van 'n buite-invloed, naamlik die optrede van sekere besoekers uit Judea. Laasgenoemde wou die bekeerlinge uit die heidendom dwing om soos Jode te lewe. Die besluitnemingsproses in Handelinge 15 vind plaas in die bepaalde spanningsveld van 'n kerklike praksis wat dreig om in twee uiteenlopende standpunte te poraliseer en lidmate in die proses van mekaar te vervreem:

- Aan die een kant het die mense wat uit Judea gekom het die klem op die behoud van die gebruike van Moses geplaas, waardeur verseker sou kon word dat die kerk nie deur onsuiwerhede verswelg sou word nie. Die aanhangers van hierdie siening het dit as 'n uitgemaakte saak beskou dat die volle gehoorsaamheid aan die heiligende implikasies van die wet die besnydenis ingesluit het. Die nie-Jode wat lidmate van die kerk geword het, sou dan besny moes word.

- Aan die ander kant het gelowiges, waaronder Paulus en Barnabas, die vryheid waartoe alle lidmate van die kerk geroep is, benadruk. Christus het die gelowiges uit die heidene vrygemaak om waarlik vry te wees. Hiervolgens moes die mense uit die heidene wat tot die Christelike geloof bekeer is, nie weer onder ' $n$ slawejuk ingedwing word nie.

Green (2002:655) toon aan dat die Christelike kerk 'n kenmerkende eenheid geopenbaar het, naamlik 'n eenheid in belydenis aangaande die werk en verdienste van Jesus Christus en juis dít het die besluit in Handelinge 15 as uitdrukking van hierdie diepgewortelde eenheid noodsaaklik gemaak. Die byeenkoms van gelowiges in Handelinge 15 handel dus nie oor die skep van 'n strukturele eenheid of 'n kerkverband nie, maar wel oor die handhawing en uit- 
breiding van die eenheid tussen die gelowiges in hulle verhouding tot Jesus Christus, onder die leiding van die Heilige Gees (Venter, 1988:39). Slegs deur die Gees kon daar gekom word tot belewing van die eenheid in Christus. Grogan (2002:661) toon in sy navorsing aan dat die pneumatologie eie aan Handelinge is en dat die besluitneming waarvan daar in Handelinge 15 sprake is, nie hiervan geskei kan word nie. Venter (1988:19) het aangetoon dat die Heilige Gees in die opbou van gemeentes - soos dit in Handelinge beskryf word - gebruik gemaak het van apostels, voorgangers en individuele gelowiges wat afsonderlik en gesamentlik in die gemeente tot woord en daad oorgegaan het. Die werking van die Heilige Gees het gelowiges dus bemagtig tot woorde, dade en derhalwe ook tot besluitneming. Grogan (2002:661) maak die gevolgtrekking dat die Heilige Gees in die Vroeë Kerk die eenheid tussen die gelowiges moontlik gemaak het, te midde van die diverse samestelling en standpunte van die destydse kerk.

In die spanningsveld van dreigende verdeeldheid wat deur besluitneming tot eenheid gebring moes word, kom die dimensie van die verhouding tussen die teonome ("die Heilige Gees") en die antroponome ("ons") na vore. Die Heilige Gees het die gelowiges in hulle beraadslagings nie op 'n willose en meganiese wyse gelei nie. Grogan (2002:662) benadruk die feit dat die Gees die gelowiges gelei het om langs die weg van redevoering en oorweging en studie van die Woord van God tot 'n besluit te kom. In hierdie proses van menslike interaksie, oorredingskommunikasie en oordeelvorming met die oog op verantwoordelike besluitneming, het die besef van die afhanklikheid van die Heilige Gees sentraal gestaan:

- In Handelinge 15:8 beroep Petrus hom op die feit dat die

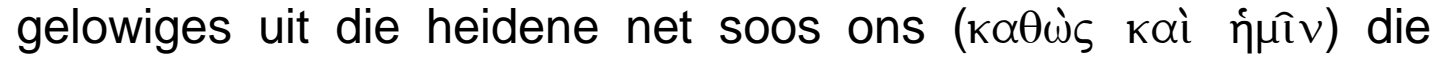
Heilige Gees ontvang het.

- In vers 11 word die volgorde van vers 8 omgedraai. In vers 8 is gesê dat die gelowiges uit die heidene ook die Gees ontvang het, terwyl vers 11 sê dat gelowiges uit die Jode net soos die heidene

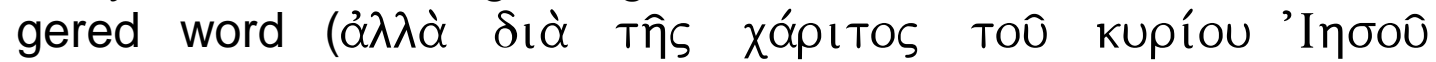

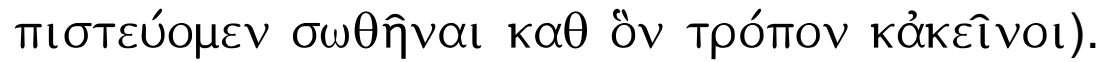

- In vers 11 maak die apostel Petrus duidelik dat die gemeenskaplike faktor van die werking van die Gees, in die gelowiges uit die Jode sowel as die gelowiges uit die heidene, in deelgenootskap aan die reddende genade van die Here Jesus geleë is. Deur die onwrikbare geloof in die besef dat die verlossing in Christus geskied, word die fondament gelê dat "hulle" en "ons" 
een gemeenskap - 'n gemeenskap van ons - kan vorm. Dit is opmerklik dat daar op grond van hierdie belydenis stilte in die vergadering kom (Hand. 15:12). Die vergadering was nou bereid om te luister.

- Uit verse 22 en 28 blyk dit dat die Heilige Gees die gelowiges tot ' $n$ soort besluitneming gelei het waarin die belange van een groep nie teenoor dié van 'n ander afgespeel is nie. Die woorde in Handelinge 15:28 "Die Heilige Gees en ons het besluit"

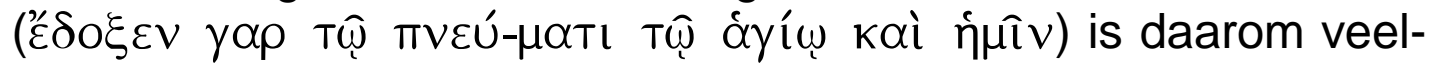
seggend vir die eensgesindheid waarmee die gelowiges tot besluitneming kon kom. Hier is sprake van mense wat hulle bewustelik, gewillig en eerste van alles, onder leiding van die Heilige Gees geplaas het en sodoende nie deur die vooropstelling van eie belang tot eensydige en verengende besluitneming gekom het nie.

Die gelowiges het nie die gees geopenbaar van "ons maak wat ons wil" nie. Vanuit die redevoerings deur Petrus en Jakobus blyk die besef dat gelowiges coram Deo lewe, praat en besluit. Van't Spijker (1993:435) benadruk daarom die feit dat die Heilige Gees op sy unieke verhewe wyse in menseharte werk. Hy toon verder aan dat daar waar die Gees en Woord vooropstaan, die vrugte van die Woord aangetref word (Van't Spijker, 1993:442). Waar die Gees en Woord saamwerk, vind die gesagvolle werking van die Heilige Gees in gelowiges plaas, sodat dit die Heilige Gees is wat dring en oortuig. Sonder die innerlike en transformerende werking van die Heilige Gees bly mense altyd toegespin in selfsug en die onaangename vrugte van antroponome denkpatrone (Van Wyk, 1990: 269).

Die volgende basisteoretiese gevolgtrekkings kan gemaak word oor die verhouding tussen die teonome en antroponome aspekte in kerklike besluitneming:

- Die Heilige Gees staan sentraal in die manier waarop gelowiges met mekaar omgaan en bied nie slegs 'n fondament vir eenstemmige ontplooiing en vorming van denke nie, maar lei ook bewustelik tot besluitneming waarin niemand onnodig belas of gemarginaliseer word nie. Die Gees getuig van Jesus se verlossingswerk en lei gelowiges, uit watter agtergrond hulle ook al kom, tot volle deelgenootskap aan die vrugte van hierdie verlossingswerk. 
- Die Heilige Gees het oortuigende krag en lei tot eenheid, ook daar waar gelowiges ingebed is in 'n situasie wat potensieel op strydpunte met mekaar kan uitloop.

- In die beraadslaging en besluitneming van gelowiges werk die Heilige Gees nie op meganiese wyse nie. Daarom rus daar 'n verantwoordelikheid op gelowiges in hulle (kerklike) beraadslaging en besluitneming.

- Wanneer gelowiges in besluitneming nie voluit rekening hou met die werking van die Heilige Gees nie en die werking van die Gees selfs weerstaan, word eiewillige besluite geneem. Eenheid word in die gedrang gebring wanneer daar aan een groep se belange ten koste van 'n ander groep s'n gevolg gegee word.

\subsection{Basisteoretiese perspektiewe op Skrifgebruik en die onderliggende gesagstruktuur daarvan vir verantwoordelike oordeelvorming in kerklike besluitneming}

Die vergadering van gelowiges in Handelinge 15 dui die kontoere van die propria (die wesenseie) van kerklike besluitneming aan (De Villiers, 1987:43). Omdat kerklike vergaderings die gesag van Christus moet bedien soos Hy dit in sy Woord beveel, moet vergaderings dit doen in die lig van die Woord en onder leiding van die Heilige Gees. Die aktiwiteit wat elders in die Bybel hieraan gekoppel word, word saamgetrek in die begrip oordeel of ondersoek. In Handelinge

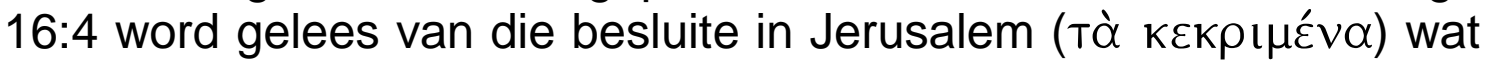
Paulus en Timoteüs aan die gelowiges in Derbe en Listra oorgedra

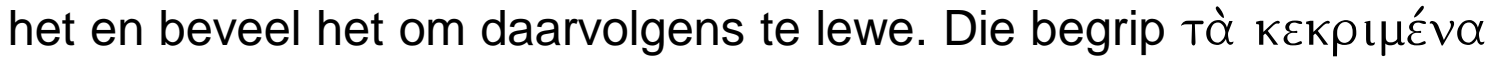
(bes/uite) het volgens Bromiley (1985:469) die betekenis om soos 'n regter te oordeel, of te evalueer in die lig van die Skrif. Louw en Nida

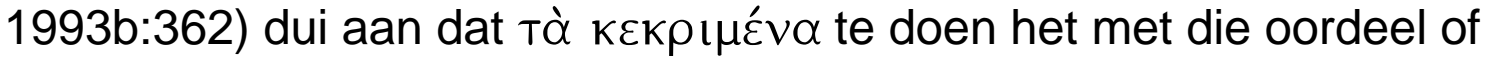
' $n$ bepaalde saak beter as ' $n$ ander saak is sodat die waardevolheid en geldigheid daarvan sal blyk. In Handelinge 16:5 word gelees dat die besluit van die vergadering in Handelinge 15, as oordeel van die Skrif, twee positiewe dinge tot gevolg gehad het, naamlik versterking in die geloof en die uitbreiding van die kerk.

Kerklike besluitneming en die verantwoordelike oordeelsvorming waarop dit berus, kan alleen ooreenkomstig die toetssteen van die Woord gevorm word en nie deur die gewigtigheid van 'n blote meerderheid van stemme bepaal word nie. Kerklike besluitneming word nie primêr deur die kwantiteit van stemme bepaal nie, maar deur die kwaliteit hiervan. Indien besluite nie mutua consensus (by 
wyse van wedersydse instemming) geskied nie, maar by wyse van consensus omnium ('n blote meerderheid van stemme), ontstaan die moontlikheid dat daar 'n heerskappy van mense intree (Van der Walt, 1976:143). Antroponome besluite gee nie aanleiding tot versterking in die geloof nie en bevorder allermins kerkgroei. Groenewald (1986:468) beskryf daarom die status van die vergadering in Handelinge 15 as ' $n$ vergadering van die kerkraad van Jerusalem, waarby 'n afvaardiging (deputasie) uit Antiochië 'n adviesvraag voorgelê het. Die basis van die besluitneming by die vergadering van Handelinge 15 was nie die sentimente van die meerderheid óf die gesag van die menslike tradisie nie, maar wel die boodskap aangaande Jesus Christus soos dit uit die Skrif en Skrifvervulling blyk (vgl. Wiarda, 2003:245). Groenewald (1986:466) toon aan dat indien die besluit in Jerusalem nie die boodskap van die evangelie bevestig het nie, dit op 'n skeuring in die jong kerk van Antiochië sou uitgeloop het. Kerklike besluitneming dra daarom altyd die kiem in homself dat dit gelowiges uitmekaar kan dryf of, positief gestel, nader aan die kernsaak, naamlik God se Woord kan bring. In die besluit wat kerklike vergaderings neem, moet die verbondenheid aan die evangelie altyd duidelik blyk (De Villiers, 1987:43). Om uit die Gees te lewe en te besluit, spruit egter voort vanuit 'n lewenswyse uit die Woord (Van't Spijker, 1993:443).

In die verloop van die kerklike vergadering van Handelinge 15 blyk die teonome Woordbepaaldheid van die besluitnemingsproses duidelik:

- Die apostels en ouderlinge in Jerusalem was die persone na wie die jong gemeente van Antiochië opgesien het om uit die lig van die Woord die spanning op te los. Dit is opmerklik dat die apostels en die ouderlinge tydens hierdie beraadslagings daarin slaag om deur die polariserende denke van die gelowiges wat vroeër Fariseërs was, nie ingeperk te word nie. In sy spreekbeurt beroep Petrus hom op 'n baie belangrike saak, naamlik die feit dat God

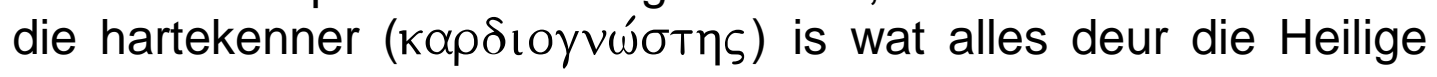
Gees bevestig. Die woord wat hiervoor gebruik word, is 'n saamgestelde woord wat bestaan uit hart en weet (ken). Louw en Nida

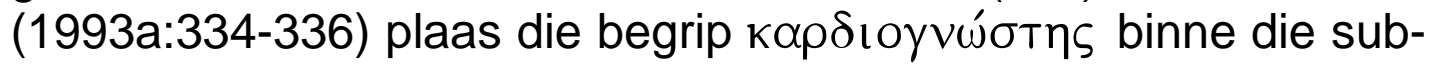
domein van om te weet. Die begrip dui op iemand wat presies weet wat ander dink. Hierdie begrip word slegs twee maal in die Nuwe Testament aangetref, naamlik in Handelinge 1:24 en in Handelinge 15:8. Op grond hiervan maak Bromiley (1985:416) en Brown (1986:553) die afleiding dat selfs die innerlike van die mens, waarin die ware gesindheid teenoor Hom geleë is, vir die 
Here bekend is. Die Here het dit alles bevestig deur die Heilige Gees ook aan die gelowiges uit die heidene te gee

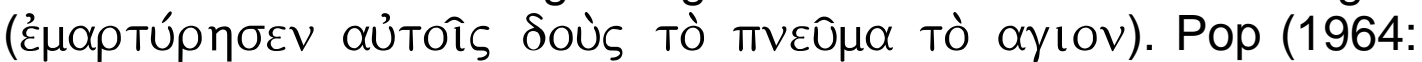
241) sien in hierdie beskrywing van die Heilige Gees as Bevestiger van God se optrede, nie alleen die algemene betekenis van getuienis wat gelewer word nie, maar ook die gedagte van iemand wat die waarheid vertolk. Die waarheid van die evangelie, naamlik dat gelowiges deur Christus gered word en dat almal se harte deur die verkondiging van die evangelie gereinig word (al het hulle nie deel aan die uiterlike reinigingsteken van die besnydenis nie), is 'n saak waaroor die Heilige Gees getuig. God gee op hierdie wyse self die waarborg vir die egtheid van die waarheid van die verlossing. Hierdie gedagte, naamlik dat God self getuig van die ware reiniging wat in mense se harte bewerk word deur die verkondiging van die evangelie, sou beskryf kon word as die filter van die bespreking en latere besluitneming. Die besluitnemers laat hulle uiteindelik deur God self lei en nie deur hulle eie antroponome voorkeure of tradisionele persepsies (uiterlike besnydenis en onderhoud van die wet van Moses as bewerking van reiniging voor God) nie.

- Jakobus, die voorsitter van die vergadering wat 'n leidende rol in die gemeente van Jerusalem gespeel het, toets die argumente wat gedebatteer is en die getuienis van Barnabas en Paulus oor die tekens en wonders wat God deur hulle onder die heidennasies verrig het (v. 12) ooreenkomstig die toetssteen van die Woord van God. Dit wat onder die heidennasies gebeur, word as 'n vervulling van die Skrif verklaar (v. 13-18; vgl. Amos 9:11-12).

- Op grond van die toets van die altyd geldende Woord van God ("Elke sabbatdag word dit in die sinagoges gelees"), lewer Jakobus sy normerende konklusie in Handelinge 15:19-21. Die Woord word op 'n manier gebruik dat daar - getrou aan die een wat die Woord gee om mense se lewens te laat floreer - nie 'n onnodige las op die skouers van die gelowiges uit die heidene geplaas word nie. Die Woord word tegelykertyd ook op so 'n manier gebruik dat die vrese van 'n onverantwoordelike aanpassing van die Skrif wat op uitrafeling van 'n heilige lewe voor God sou uitloop, besweer word. Teonome Skrifgebruik bring eenheid en rus in die gemeenskap van gelowiges. Teonome Skrifgebruik word nie ingetrek in 'n spanningsveld waarin menslike voorkeure, óf onverantwoordelike uitleef van vryheid, óf wettisistiese bewaring van reinheid die deurslag gee nie. 


\section{Samevatting}

In hierdie artikel is fase een en twee van die navorsingprojek opgeteken. Daar is gepoog om konsekwent met die volgende navorsingvraag te werk: In hoe 'n mate het die problematiese praksis rondom kerklike besluitneming te make met 'n oorvereenvoudigde persepsie rakende die pneumatologiese dinamika wat ter sprake kom in besluite waarvan gesê word: "die Heilige Gees en ons het besluit"? Die navorsers is van mening dat die verkenning van hierdie navorsingsvraag en die metateoretiese en basisteoretiese perspektiewe aangedui het dat besluitneming ' $n$ komplekse proses is. Wanneer nie rekening gehou word met antroponome faktore nie, kan dit in polarisasie ontspoor. In verantwoordelike kerklike besluitneming en Skrifhantering wat daarmee gepaard gaan, sal diegene wat tot besluitneming geroep is, toegerus moet word om hulle bewustelik deur die Gees van God te laat lei met die oog op die hart van die evangelie van genade in Jesus Christus, wat die integrasiepunt vir kerklike eenheid is.

In 'n opvolgartikel sal op praktykteoretiese vlak besin word oor 'n handelingspraksis waarin die kompleksiteit van die verhouding tussen Goddelike en menslike elemente in die besluitnemingsproses gevisualiseer kan word, rakende die faktore wat in mense aan die werk is tydens so 'n besluitnemingsproses. Die doel van die praktykteoretiese merkers is om aan deelnemers aan besluitneming ' $n$ klankbord te gee om te groei in 'n sensitiwiteit vir die maniere waarop sekere faktore - sonder dat 'n mens daarvan bewus is - jou oordeel in 'n sekere rigting kan manipuleer. Uiteindelik sou die praktykteoretiese merkers hopelik as hulplyne vir die kanalisering van ' $n$ besluitnemingsproses kon funksioneer, waarin die orde en die ontsaglike ruimtes van vryheid wat die Here vir sy kerk oopgemaak het vir alle gelowiges oopgaan en hulle tot ware eenheid in een Here saamgebind word.

\section{Geraadpleegde bronne}

BARON, R.A. \& BYRNE, D. 1994. Social psychology. Boston: Allyn \& Bacon.

BLACKABY, H.T. \& KING, C.V. 2002. Beleef God: hoe om God se wil te ken en te doen. Wellington: Lux Verbi.BM.

BROMILEY, G.W. 1985. Ta kekremina. (In Douglas, J.D., Hillyer, N., Bruce, F.F., Guthrie, D., Millard, A.R., Packer, J.I. \& Wiseman, D.J., eds. Theological Dictionary of the New Testament. Grand Rapids: Eerdmans. p. 422-423.)

BROWN, C. 1986. Kardiognoostes. (In Coenen, L., Beyreuther, E. \& Bietenhard, H., eds. The New International Dictionary of the New Testament Theology. Vol 3. Grand Rapids: Zondervan. p. 551-553.) 
BURGER, C.W. 1994. Die agogiese moment in die prediking in 'n situasie van verandering. Praktiese teologie in Suid Afrika, 9(1):83-92.

BURGER, C.W. 1995. Gemeentes in transito: vernuwingsgeleenthede in 'n oorgangstyd. Kaapstad: Lux Verbi.

CALVYN, J. 1956. Institutie of onderwyzing in de Christelijke godsdienst. 3 dele. 4 e dr. Uit Latyn vertaal deur A. Sizoo. Delft: Meinema.

CARTLEDGE, M.J. 2003. Practical theology: charismatic and empirical perspectives. London: Paternoster.

DE KLERK, B.J. 2000. Gewetebinding, Calvyn en die viering van die Nagmaal. In die Skriflig, 34(3):333-350.

DE VILLIERS, P. 1987. Die apostelkonvent. (In Breytenbach, C. \& Du Toit, A., reds. Eenheid en konflik. Kaapstad: Goodwood. p. 23-49.)

DE WET, F.W. 2005. Om in die Gees te begin en in eie krag te eindig: die noodsaak van 'n Skrifgefundeerde prakties-teologiese pneumatologie. In die Skriflig, 39(3):505-527.

DE WET, F.W. 2009. Die implikasies van 'n pneumatologies-bepaalde teoretiese raamwerk vir navorsingsmetodologie in prakties-teologiese wetenskapsbeoefening. In die Skriflig, 43(2):1-24.

DINGEMANS, G.D.J. 1996. Manieren van doen: inleiding tot de studie van de praktische theologie. Kampen: Kok.

DUDLEY, C.S. \& HILGERT, E. 1987. New Testament tensions and the contemporary church. Philadelphia: Fortress.

FIRET, J. 1978. Het agogisch moment in het pastoraal optreden. Kampen: Kok.

FIRET, J. 1987. Spreken als een leerling: praktisch-teologische opstellen. Kampen: Kok.

GASS, R.H. \& SEITER, J.S. 2003. Persuasion, social influence and compliance gaining. New York: Harper Collins.

GREEN, M. 2002. Good news from the first Christians. (In Alexander, D. \& Alexander, P., eds. The lion handbook to the Bible. Oxford: Lion Hudson. p. 655-656.)

GROENEWALD, E.P. 1986. Handboek Bybelse geskiedenis. Pretoria: NG Kerkboekhandel.

GROGAN, G.W. 2002. The Holy Spirit in Acts. (In Alexander, D. \& Alexander, P., eds. The lion handbook to the Bible. Oxford: Lion Hudson. p. 661-662.)

HEITINK, G. 1999. Practical theology: history, theory, action domains: manual for practical theology. Grand Rapids: Eerdmans.

HEYNS, L.M. \& PIETERSE, H.J.C. 1990. Eerste treë in die praktiese teologie. Pretoria: Promedia.

JORDAAN, G.J.C. 1997. Gewetensbinding. Die Kerkblad: 6-7, Jan.

LOUW, D. \& EDWARDS, D. 1998. Sielkunde: 'n inleiding vir studente in SuiderAfrika. Sandton: Heinemann.

LOUW, D.J. 1993. Pastoraat as ontmoeting: ontwerp vir 'n basisteorie, antropologie en terapie. Pretoria: RGN.

LOUW, J.P. \& NIDA, E.A.1993a. Kardiognoostes. (In Smith, R.B., Munson, K.A., Louw, J.P. \& Nida, E.A., eds. Greek English Lexicon of the New Testament. New York: United Bible Studies. p. 334-336.)

LOUW, J.P. \& NIDA, E.A.1993b. Ta kekrimena. (In Smith, R.B., Munson, K.A., Louw, J.P. \& Nida, E.A., eds. Greek English Lexicon of the New Testament. New York: United Bible Studies. p. 362.)

NEL, A. 2003. Op soek na God buite die kerk. Wellington: Lux Verbi.BM. 
NIEMANDT, N. 2007. Sal die kerk van die toekoms vandag oorleef? (In Joubert, S., Van der Watt, J., Sweet, I., Easum, B. \& Niemandt, N., reds. Die perfekte storm. Vereeniging: Christelike Uitgewersmaatskappy. p. 45-63.)

NOBLE, T. 2000. Social theory and social change. New York: St. Martin's.

PIENAAR, A. 2009. Eerder vroeër as later. Die Kerkbode: 8, 7 Aug.

PIETERSE, H.J.C. 1981. Die daad by die woord. Pretoria: NG Kerkboekhandel.

PIETERSE, H.J.C. 2005. Hoe kom God aan die Woord in die prediking? Die probleemstelling. Praktiese teologie in Suid- Afrika, 20(1):77-95.

POP, F.J. 1964. Kardiognoostes: Bybelse woorde en hun geheim. 's Gravenhage: Boekencentrum. p. 241. )

REBEL, J.J. 1982. Pneumatologie en pastoraat. Theologia reformata, 25(3): 155-169.

SMIT, A. 1995. Nuut gedink oor leierskap in gemeentes. (In Burger, C., Hendriks, J., Van der Merwe, M. \& Smit, A., reds. Gemeente en bediening: nuut gedink oor leierskap in gemeentes - die begeleiding van 'n Christelike gemeenskap. Kaapstad: Lux Verbi. p.121-122.)

SMIT, C.J. 1992. Kerkregering as 'n geestelike regeringswyse. In die Skriflig, 26(4):503-521.

SMIT, P.J. \& DE CRONJE, G.J. 1999. Management principles. Kenwyn: Juta.

SNYMAN, G. 1992. Binnegevegte in die GKSA: verskuiwing van plausibility structures. In die Skriflig, 26(3):351-367.

SNYMAN, G. 2009. Kon GKSA anders oor vroue besluit? Die Kerkbode: 9, 7 Aug.

SUGGIT, J.N. 1992. "The Holy Spirit and we resolved ..." (Acts 15:28). Journal of theology for Southern Africa, 79:38-48.

SWEET, L. 2007. Sal die kerk van die toekoms vandag oorleef? (In Joubert, S., Van der Watt, J., Sweet, I., Easum, B. \& Niemandt, N., reds. Die perfekte storm. Vereeniging: Christelike Uitgewersmaatskappy. p.15-44.)

TIMASHEFF, N.S. \& THEODORSON, G.A. 1983. Sociological theory. New York: Random House.

VAN DER WALT, J.J. 1976. Christus as Hoof van die kerk en die presbiteriale kerkregering. Potchefstroom: Pro Rege.

VAN DER WATT, J. 2007. Sal die kerk van die toekoms vandag oorleef? (In Joubert, S., Van der Watt, J., Sweet, I., Easum, B. \& Niemandt, N., reds. Die perfekte storm. Vereeniging: Christelike Uitgewersmaatskappy. p. 6377.)

VAN PELT, J.W. 1999. Pastoraat in trinitarisch perspectief: die samehang tussen trinitarische en antropologische aspecten in het pastoraat. Heerenveen: Groen.

VAN RULER, A.A. 1969. Theologisch werk. DI. 1. Nijkerk: Callenbach.

VAN WYK, J.H. 1990. Direktiewe by morele keuses. In die Skriflig, 24(3):265282.

VAN WYK, J.H. 2009. Drie debatte, baie vrae. Beeld: 7, 28 Jun.

VAN'T SPIJKER, W.1993. De spiritualiteit van de charismatici. (In Balke, W., Exalto, K., Van Driel, L. \& Van't Spijker, W., reds. Spiritualiteit. Kampen: De Groot Goudriaan. p. 435-452.)

VENTER, A.G.S. 1988. Die werk van die Heilige Gees in die opbou van die kerk volgens Handelinge. In die Skriflig, 22(86):15-40.

VORSTER, J.M. 2008. En die sinode sal besluit. Die Kerkblad: 8-9, Nov.

WIARDA, T. 2003. The Jerusalem council and the theological task. Journal of the evangelical theological society, 46(2):233-248. 


\section{Kernbegrippe:}

kerklike besluitneming

prakties-teologiese benadering

verhouding: teonome en antroponome

Key concepts:

ecclesiastical resolution making

practical-theological approach

relationship: teonomic and anthroponomic 
'n Prakties-teologiese perspektief op die handeling van kerklike besluitneming ... 